\title{
PROBLEMATIKA HUKUM PERKAWINAN DI INDONESIA
}

\author{
Novita Lestari \\ Fakultas Hukum Universitas Dehasen Bengkulu (UNIVED) \\ Jl. Meranti Raya No.32, Sawah Lebar, Ratu Agung, Bengkulu, 38222 \\ Email: novi.lestari@gmail.com
}

\begin{abstract}
Indonesia is a very plural country, consisting of various tribes, groups, races and religions and rich in culture. The heterogeneity of Indonesian society makes it possible for marriages of different religions and other forms of marriage. The special law regulating marriage is Law Number 1 Year 1974. Many parties assume that Law Number 1 Year 1974 needs to be revised because the law has been too long and can not solve some problems of marriage in the modern era . Therefore, there are still many rules that need to be changed or added in the Marriage Law, for example about the rules / provisions regarding strict sanctions for marriage offenders, whether for the perpetrators of religious marriages, similar marriages, marriage sirri and contract marriage.
\end{abstract}

Keywords: problematic, marriage law, Indonesia

\begin{abstract}
Abstrak: Indonesia merupakan negara yang sangat pluralistik, terdiri dari berbagai macam suku, golongan, ras dan agama serta kaya akan budaya. Heteroginitas masyarakat Indonesia sangat memungkinkan terjadinya perkawinan beda agama dan bentuk-bentuk perkawinan lainnya. Undang-Undang khusus yang mengatur mengenai perkawinan yakni UndangUndang Nomor 1 Tahun 1974. Banyak pihak yang bersumsi bahwa Undang-Undang Nomor 1 Tahun 1974 perlu segera direvisi karena undang-undang tersebut sudah terlalu lama dan tidak dapat menyelesaikan beberapa masalah perkawinan di era modern. Karena itu, masih banyak aturan yang perlu diubah maupun ditambah di dalam Undang-Undang Perkawinan, misalnya mengenai aturan/ketentuan mengenai sanksi yang tegas bagi para pelanggar hukum perkawinan, baik itu bagi pelaku perkawinan beda agama, perkawinan sejenis, perkawinan sirri maupun perkawinan kontrak.
\end{abstract}

Kata Kunci: problematika, hukum perkawinan, Indonesia

\section{Pendahuluan}

Sumber pokok dari segala peraturan perundang-undangan Negara Republik Indonesia adalah Pancasila dan UUD Tahun 1945. Salah satu sila dari Pancasila dan menempati sila pertama adalah Ketuhanan Yang Maha Esa. Sila ini juga tercantum dalam UUD 1945, salah satu pasal dari UUD 1945 itu menetapkan jaminan negara terhadap pelaksanaan ajaran agama masing-masing. ${ }^{1}$ Masyarakat Indonesia tergolong heterogen dalam segala aspeknya. Dalam aspek agama jelaslah bahwa terdapat dua kelompok besar agama yang diakui di Indonesia yakni: Agama Samawi dan Agama non Samawi;

\footnotetext{
${ }^{1}$ Amir Syarifuddin, Hukum Perkawinan Islam di Indonesia; Antara Fiqh Munakahat Dan Undang-Undang Perkawinan, (Jakarta: Kencana, 2009), h. 22-23.
}

agama Islam, Hindu, Budha, Kristen Protestan dan Katholik. Keseluruhan agama tersebut memiliki tata aturan sendiri-sendiri baik secara vertikal maupun horisontal; termasuk di dalamnya tata cara perkawinan. ${ }^{2}$

Ada beberapa hukum perkawinan yang berlaku bagi berbagai golongan warga negara dan berbagai daerah seperti berikut: 1. Bagi orang-orang Indonesia asli yang beragama Islam berlaku Hukum Agama yang telah diresepeier dalam Hukum Adat (pasal 134 ayat (2) IS). 2. Bagi orang-orang Indonesia lainnya berlaku Hukum Adat. 3. Bagi orang Indonesia yang beragama Kristen berlaku Huwelijke Ordonantie

${ }^{2}$ Sudarsono, Hukum Perkawinan Nasional, (Jakarta: Rineka Cipta, 2005), h. 6. 
(Kristen Indonesia S. 1933 No. 74). 4. Bagi orang Timur Asing. Cina dan warga negara Indonesia keturunan Cina berlaku ketentuan Kitab Undang-undang Hukum Perdata dengan sedikit perubahan. 5. Bagi orang-orang Timur Asing lainnya dan warga negara Indonesia keturunan Timur Asing lainnya tersebut berlaku Hukum Adat mereka. 6. Bagi orang-orang Eropa dan warga negara Indonesia keturunan Eropa dan yang disamakan dengan mereka berlaku Kitab Undang-undang Hukum Perdata. 7. Sejak 1 Oktober 1975 berlaku efektif untuk semua golongan Undangundang Nomor 1 Tahun 1974 beserta peraturan pelaksanaannya. ${ }^{3}$

Hukum perkawinan yang berlaku bagi tiaptiap agama tersebut satu sama lain ada perbedaan, akan tetapi tidak selalu bertentangan. Adapun di Indonesia telah ada hukum perkawinan yang secara otentik diatur di dalam UU No. 1 Tahun 1974 Lembaran Negara RI. Adapun penjelasan atas Undang-undang tersebut dimuat di dalam Tambahan Lembaran Negara Republik Indonesia Nomor 3019. Bagi suatu negara dan bangsa seperti Indonesia adalah mutlak adanya Undang-undang Perkawinan Nasional yang sekaligus menampung prinsip-prinsip dan memberikan landasan hukum perkawinan yang selama ini menjadi pegangan dan telah berlaku bagi berbagai golongan dalam masyarakat kita. ${ }^{4}$

Sesuai dengan landasan falsafah Pancasila dan Undang-undang Dasar 1945, maka Undangundang ini di satu pihak harus dapat mewujudkan prinsip-prinsip yang terkandung dalam Pancasila dan UUD 1945. Sedangkan di lain pihak harus dapat pula menampung segala kenyataan yang hidup dalam masyarakat dewasa ini. Undangundang perkawinan ini telah menampung di dalamnya unsur-unsur dan ketentuan-ketentuan Hukum Agamanya dan kepercayaannya itu dari yang bersangkutan. ${ }^{5}$

Adapun yang sudah menjadi peraturan per-

${ }^{3}$ Idris Ramulyo, Hukum Perkawinan Islam; Suatu Analisis Dari UU No.1 Tahun 1974 Dan Kompilasi Hukum Islam, (Jakarta: Bumi Aksara, 2004), h. 55.

${ }^{4}$ Sudarsono, Loc Cit. h. 6.

${ }^{5}$ Ibid., h. 7. undang-undangan negara yang mengatur perkawinan yang ditetapkan setelah Indonesia merdeka adalah: a. Undang-undang No. 32 Tahun 1954 tentang Penetapan Berlakunya Undang-undang Republik Indonesia Tanggal 21 November 1946 No. 22 Tahun 1946 tentang Pencatatan Nikah, Talak, dan Rujuk di seluruh daerah Luar Jawa dan Madura. b. Undang-undang No. 1 Tahun 1974 tentang Perkawinan, yang merupakan hukum materiil dari perkawinan. c. Peraturan Pemerintah No. 9 Tahun 1975 tentang Pelaksanaan Undangundang No. 1 Tahun 1974 tentang Perkawinan. d. Undang-undang No. 7 Tahun 1989 tentang Peradilan Agama Sebagian dari materi undangundang ini memuat aturan yang berkenaan dengan tata cara (hukum formil) penyelesaian sengketa perkawinan di Pengadilan Agama.

Berdasarkan beberapa hukum perundangundangan tersebut di atas fokus penelitian ini lebih diarahkan kepada UU No. 1 Tahun 1974, karena hukum materiil perkawinan keseluruhannya terdapat dalam UU ini. Di samping peraturan perundang-undangan negara yang disebutkan di atas dimasukkan pula dalam pengertian UU Perkawinan dalam bahasan ini aturan atau ketentuan yang secara efektif telah dijadikan oleh hakim di Pengadilan Agama sebagai pedoman yang harus diikuti dalam penyelesaian perkara perkawinan, yaitu Kompilasi Hukum Islam di Indonesia yang penyebarluasannya dilakukan melalui Instruksi Presiden RI No. 1 Tahun 1991 tentang Kompilasi Hukum Islam.

Salah satu tujuan Syari'at Islam adalah memelihara kelangsungan keturunan melalui perkawinan yang sah menurut agama, diakui oleh Undang-undang dan diterima sebagai bagian dari budaya masyarakat. ${ }^{6}$ Pengertian perkawinan menurut Undang-undang Perkawinan No. 1 Tahun 1974 pasal 1 menyebutkan sebagai berikut: Perkawinan adalah ikatan lahir batin antara seorang pria dengan seorang wanita

${ }^{6}$ Fuaddudin, Pengasuhan Anak dalam Keluarga Islam, Lembaga Kajian Agama dan Jender, Jakarta, 1999, h. 4. 
sebagai suami-isteri dengan tujuan membentuk keluarga (rumah tangga) yang bahagia dan kekal berdasarkan Ketuhanan Yang Maha Esa. Tujuan dari perkawinan adalah: (1) menyatukan dua pribadi yang berbeda untuk mencapai satu tujuan sebagai keluarga yang bahagia, melanjutkan keturunan yang merupakan sambungan hidup dan menyambung cita-cita, (3) menjaga diri dari perbuatan-perbuatan yang dilarang oleh Tuhan, dan (4) menimbulkan rasa cinta antara suami dan isteri.

Seiringan dengan berkembangnya masyarakat, permasalahan yang terjadi semakin kompleks. Berkaitan dengan perkawinan, belakangan ini sering tersiar dalam berbagai media terjadinya perkawinan yang dianggap problematis dalam kehidupan bermasyarakat. Sebagai contoh, perkawinan campuran, perkawinan sejenis, kawin kontrak, nikah siri, dan perkawinan antara pasangan yang memiliki keyakinan (agama) yang berbeda. Walaupun perkawinan campuran dan perkawinan beda agama sama sekali berbeda, bukan tidak mungkin pada saat yang sama perkawinan campuran juga menyebabkan perkawinan beda-agama. Hal ini disebabkan karena pasangan yang lintas negara juga pasangan lintas agama. Selain permasalahan yang berhubungan dengan pengakuan negara atau pengakuan dari kepercayaan/agama atas perkawinan, pasangan yang melaksanakan perkawinan tersebut seringkali menghadapi masalahmasalah lain yang terjadi di kemudian hari. Misalnya saja, pengakuan negara atas anak yang dilahirkan, masalah perceraian, pembagian harta ataupun masalah warisan. Belum lagi, dampakdampak lainnya.

Menurut Pasal 57 UU No. 1 Tahun 1974 tentang Perkawinan, perkawinan campuran adalah perkawinan antara dua orang yang di Indonesia tunduk pada hukum yang berlainan, karena perbedaan kewarganegaraan dan salah satu pihak berkewarganegaraan Asing dan salah satu pihak berkewarganegaraan Indonesia. Jadi, perkawinan campuran bukanlah perkawinan antar agama yang dimaksudkan di sini.
Sedangkan perkawinan beda agama masih terdapat pro-kontra di tengah-tengah masyarakat. Salah satu pendapat mengatakan bahwa masalah agama merupakan masalah pribadi sendiri-sendiri sehingga negara tidak perlu melakukan pengaturan yang memasukkan unsurunsur agama. Namun, di pihak lain, ada yang berpendapat bahwa perkawinan beda-agama dilarang oleh agama sehingga tidak dapat diterima. Setiap agama, baik itu Islam, Katolik, Protestan, Hindu maupun Budha mempunyai peraturan tentang tata cara perkawinan, syaratsyarat perkawinan atau mengenai larangan perkawinan yang masing-masing agama berbedabeda. Apabila perkawinan terjadi pada orang yang menganut agama yang sama maka tidak menjadi masalah. Permasalahan terjadi manakala mereka yang berbeda agama hendak melangsungkan perkawinan dan mereka menyadari akan arti iman, karena adanya cinta yang mendalam ingin melangsungkan perkawinan tanpa mengorbankan keimanan masing-masing. ${ }^{7}$ Untuk mencegah terjadinya perkawinan beda-agama yang biasanya salah satu pihak dari pasangan tersebut berpindah agama atau mengikuti agama salah satu pihak sehingga perkawinannya pun disahkan berdasarkan agama yang dipilih tersebut.

Permasalahan perkawinan lainnya mencakup perkawinan sejenis (kaum lesbian, gay, biseksual, transseksual/transgender) yang belum dapat diterima oleh masyarakat karena bertentangan dengan aturan agama dan norma-norma yang berlaku dalam kehidupan masyarakat, walaupun terdapat beberapa komunitas yang mempromosikan dan membela hak-hak dasar kaum LGBT (lesbian, gay, biseksual, transseksual/ transgender) atas nama hak asasi manusia.

Selain itu ada juga permasalahan dalam hukum perkawinan yaitu perkawinan/nikah sirri baik secara langsung maupun tidak langsung (online). Dewasa ini pernikahan sirri secara online (melalui teknologi internet) sudah banyak terjadi, dan menuai pro dan kontra di kalangan masyarakat.

${ }^{7}$ Lili Rasidi, Hukum Perkawinan dan Perceraian di Malaysia dan Indonesia, (Bandung: Remaja Rosdakarya, 1991), h. 17 
Nikah sirri dapat diartikan sebagai pernikahan yang rahasia atau dirahasiakan. Dikatakan sebagai pernikahan yang dirahasiakan karena prosesi pernikahan semacam ini sengaja disembunyikan dari publik dengan berbagai alasan, dan biasanya hanya dihadiri oleh kalangan terbatas keluarga dekat, tidak dimeriahkan dalam bentuk resepsi secara terbuka untuk umum. Sah tidaknya suatu pernikahan sirri diserahkan pada rukun dan syarat masing-masing agama/keyakinan, meskipun pernikahan itu tidak dicatatkan di Pejabat Pencatat Nikah (PPN). Fungsi pencatatan pernikahan untuk tertib administrasi perkawinan dan agar mempunyai kekuatan hukum

Permasalahan hukum perkawinan juga meliputi perkawinan kontrak, yaitu perkawinan yang dilakukan oleh seorang laki-laki dan seorang perempuan yang melangsungkan pernikahan dalam jangka waktu tertentu dan dituangkan ke dalam sebuah kontrak. Pelaksanaan perkawinan ini juga seperti perkawinan sirri, tanpa adanya pencatatan perkawinan. Dalam hukum Islam perkawinan kontrak disebut nikah mut'ah, perkawinan ini dilarang oleh agama Islam.

Di kehidupan modern sekarang ini, perkawinan bukan saja berakibat pada individu yang melangsungkan perkawinan tapi juga menimbulkan akibat yang luas bagi pergaulan hidup manusia. Kemajuan komunikasi serta alat transportasi semakin membuka kesempatan yang luas bagi masyarakat untuk saling mengadakan hubungan, baik antar suku, ras maupun agama. Dari hubungan-hubungan ini tidak mustahil akan terjadi perkawinan antar suku, ras dan agama dalam kehidupan masyarakat. Masyarakat Indonesia dikenal dengan masyarakat yang pluralistik atau majemuk, dilihat dari segi etnik, agama, adat istiadat maupun golongan. Karakteristik seperti ini mengakibatkan terjadinya interaksi sosial budaya yang pada gilirannya memunculkan fenomena perkawinan silang antar agama dan budaya, serta etnis maupun golongan yang berbeda. ${ }^{8}$

${ }^{8}$ Narsikun, Poligami Ditinjau dari Segi Agama. Sosial dan Perundang-undangan, (Jakarta: Bulan Bintang, 2003), h. 9.
Melihat realitas permasalahan-permasalahan dalam hukum perkawinan di Indonesia dewasa ini, penulis tertarik untuk mengkaji secara mendalam mengenai permasalahanpermasalahan apa saja dalam hukum perkawinan di Indonesia, yang meliputi permasalahan perkawinan beda agama, perkawinan sirri, perkawinan sejenis, dan kawin kontrak, dilihat dari sudut pandang peraturan perundangundangan yang berlaku di Indonesia terutama dari perspektif Undang-Undang No. 1 Tahun 1974 tentang perkawinan.

\section{Identifikasi Masalah}

Berdasarkan uraian di atas, penulisan ini akan membahas mengenai apa saja permasalahanpermasalahan dalam hukum perkawinan di Indonesia?

\section{Tujuan Penelitian}

Adapun tujuan dari penelitian ini adalah untuk mengkaji dan menganalisis permasalahanpermasalahan dalam hukum perkawinan di Indonesia, serta mengkaji dan menganalisis penyelesaian permasalahan hukum perkawinan di Indonesia.

\section{Metode Penelitian}

Metode penelitian yang digunakan dalam penelitian ini adalah dengan menggunakan metode penelitian hukum normatif. Sebagai penelitian hukum normatif, maka penelitian ini termasuk kategori tipe penelitian hukum bersifat deskriptif-preskriptif yang bertujuan menemukan solusi permasalahan (problemsolution). P Pendekatan yang digunakan dalam penelitian ini adalah metode pendekatan yuridis normatif, yaitu pendekatan yang mengkaji kaidah-kaidah hukum normatif dan doktrinal.

\footnotetext{
${ }^{9}$ Soerjono Soekanto, Pengantar Penelitian Hukum, UI Press, Jakarta, 2008, h. 50-51
} 


\section{Hasil Dan Pembahasan}

Permasalahan-Permasalahan Dalam Hukum Perkawinan Di Indonesia

Berdasarkan ketentuan Undang-Undang No. 1 Tahun 1974, perkawinan adalah ikatan lahir batin seorang pria dengan seorang wanita sebagai suami istri dengan tujuan membentuk keluarga (rumah tangga) yang bahagia dan kekal berdasarkan Ketuhanan Yang Maha Esa. Perkawinan adalah sah, apabila dilakukan menurut hukum masing-masing agamanya dan kepercayaannya, dan dicatat menurut peraturan perundang-undangan yang berlaku. Namun dewasa ini banyak perkawinan yang diselenggarakan bertentangan dengan hukum agama dan peraturan perundang-undangan yang berlaku. Adapun jenis perkawinan yang bertentangan dan dianggap melanggar hukum agama maupun hukum positif, yaitu:

\section{a. Perkawinan Beda Agama}

Perkawinan beda agama adalah perkawinan antara dua orang, pria dan wanita, yang tunduk pada hukum agama atau kepercayaan yang berlainan. Pasal 2 Ayat 1 Undang-Undang Nomor 1 Tahun 1974 berbunyi: "perkawinan adalah sah, apabila dilakukan menurut hukum masing-masing agamanya dan kepercayaannya itu”. Dalam penjelasan undang-undang perkawinan ditegaskan dengan perumusan Pasal 2 Ayat 1 tersebut, tidak ada perkawinan di luar hukum masing-masing agamanya dan kepercayaannya itu, sesuai dengan UUD 1945.

Ketentuan tersebut berarti bahwa perkawinan hanya dapat dilaksanakan jika kedua mempelai memiliki agama yang sama. Kalau keduanya memiliki agama yang berbeda, maka ada beberapa cara yang biasanya ditempuh pasangan beda agama yang akan menikah yakni, pertama, meminta penetapan pengadilan terlebih dahulu. Atas dasar penetapan itulah pasangan melangsungkan pernikahan di Kantor Catatan Sipil. Tetapi cara ini tak bisa lagi dilaksanakan sejak terbitnya Keppres No. 12 Tahun 1983. Kedua, perkawinan dilangsungkan menurut hukum masing-masing agama. Perkawinan terlebih dahulu dilaksanakan menurut hukum agama seorang mempelai (biasanya suami), baru disusul pernikahan menurut hukum agama mempelai berikutnya. Permasalahannya perkawinan mana yang dianggap sah? Ketiga, kedua pasangan menentukan pilihan hukum. Salah satu pandangan menyatakan tunduk pada hukum pasangannya. Dengan cara ini, salah seorang pasangan biasanya 'berpindah agama' sebagai bentuk penundukan hukum. Disini terlihat adanya penyeludupan hukum dimana salah satu pihak secara pura-pura beralih agama. Keempat, yang sering dipakai belakangan, adalah melangsungkan perkawinan di luar negeri. Beberapa artis tercatat memilih cara ini sebagai upaya menyiasati susahnya pelaksanaan perkawinan beda agama di Indonesia.

Menurut Undang-Undang No. 1 Tahun 1974, baik dalam pasal-pasal maupun penjelasannya serta peraturan pelaksanaannya, tidak ada ketentuan yag mengatur secara tegas mengenai perkawinan berbeda agama. Akan tetapi apabila melihat pada ketentuan Pasal 2 ayat (1) yang menyatakan baha perkawinan adalah sah apabila dilakukan menurut hukum masing-masing agamanya dan kepercayaannya itu, mengindikasikan bahwa undang-undang menyerahkan kepada masing-masing agama untuk menentukan cara-cara dan syarat-syarat pelaksanaan perkawinan, disamping cara-cara dan syarat-syarat yang telah ditetapkan oleh Negara. Dengan demikian apakah suatu perkawinan dilarang atau tidak, disamping tergantung pada ketentuan-ketentuan yang terdapat dalam Undang-Undang No. 1 Tahun 1974, juga ditentukan oleh hukum agamanya masing-masing.

Ketentuan Pasal 8 huruf f Undang-Undang No. 1 Tahun 1974 yang menyatakan bahwa perkawinan dilarang antara dua orang yang mempunyai hubungan yang oleh agamanya atau peraturan lain yang berlaku, dilarang kawin. Dari ketentuan ini dapat ditarik kesimpulan bahwa sekalipun Undang-Undang No. 1 Tahun 1974 tidak mengatur secara tegas 
mengenai perkawinan beda agama. Namun secara implisit bagi orang Islam terdapat suatu larangan sebagaimana yang ditentukan dalam agama Islam, demikian juga bagi orang Kristen, Katholik serta pemeluk agama lain.

Dalam hukum Islam perkawinan beda agama dilarang, hal ini terdapat dalam Al-Qur'an yang merupakan sumber dari hukum Islam. Larangan perkawinan beda agama tersebut tertulis dalam Q.S. Al-Baqarah ayat 221: "Dan janganlah kamu menikahi wanita-wanita musyrik, sebelum mereka beriman. Sesungguhnya wanita budak yang mukmin lebih baik dari wanita musyrik, walaupun dia menarik hatimu. Dan janganlah kamu menikahkan orang-orang musyrik (dengan wanita-wanita mukmin) sebelum mereka beriman. Sesungguhnya budak yang mukmin lebih baik dari orang musyrik, walaupun dia menarik hatimu". Berdasarkan ayat tersebut jelas bahwa perkawinan beda agama hukumnya haram. Hal tersebut dipertegas lagi dalam Kompilasi Hukum Islam (KHI) pada Pasal 40 dan 44, yang menyatakan bahwa seorang perempuan Islam tidak diperbolehkan (haram) untuk dinikahkan dengan pria nonmuslim dan demikian pula seorang pria muslim tidak diizinkan menikahi seorang wanita bukan Islam.

Larangan perkawinan beda agama umumnya juga berlaku bagi agama non Islam. Menurut agama Kristen Protestan, Gereja Protestan menghindari perkawinan beda agama. Hanya dalam keadaan yang tidak dapat dihindari Gereja akan mangizinkannya dengan persyaratan tertentu. Sedangkan menurut agama Kristen Katolik, sedapat mungkin menghindari perbedaan agama. Hanya dalam hal tertentu, dalam hal keadaan yang tidak dapat dihindari, Gereja dapat mengizinkan perkawinan beda agama. ${ }^{10}$

Menurut ajaran agama Budha setiap agama adalah baik dan setiap manusia bebas untuk memeluk agamanya masing-masing, sehingga tidak menjadi persoalan apabila seseorang yang beragama Budha hendak menikah dengan se-

${ }^{10}$ Djaja S. Meliala, Hukum Perdata Dalam Perspektif BW, (Bandung: Nuansa Aulia, 2012), h. 98 orang yang bukan beragama Budha. Sedangkan menurut agama Hindu, agama Hindu melarang perkawinan beda agama, terutama jika pihak laki-laki yang beragama Hindu, karena berbeda agama berarti berbeda prinsip. Namun, bila kedua calon mempelai tetap bersikukuh untuk melangsungkan perkawinan, upaya yang ditempuh adalah dengan mensucikan salah satu calon mempelai yang bukan beragama Hindu. ${ }^{11}$

Berdasarkan Kepres No. 6 Tahun 2000, maka agama Kong $\mathrm{Hu}$ Chu merupakan agama yang keenam yang diakui secara resmi di Indonesia. Pada prinsipnya agama Kong $\mathrm{Hu}$ Chu sama dengan agama Budha, artinya dapat memperkenankan perkawinan beda agama. ${ }^{12}$

Dalam pasal 2 ayat (2) dinyatakan bahwa "Tiap-tiap perkawinan dicatat menurut peraturan perundang-undangan yang berlaku”. Peran pemerintah hanya sebatas melakukan pencatatan nikah dan hal tersebut berarti pemerintah hanya mengatur aspek administratif perkawinan. Namun, dalam prakteknya, kedua ayat dalam Undang-Undang Perkawinan yakni pasal 2 ayat (1) dan (2) berlaku secara kumulatif sehingga kedua-duanya harus diterapkan bagi persayaratan sahnya suatu perkawinan.

Akibatnya, meskipun suatu perkawinan sudah dipandang sah berdasarkan aturan agama tertentu, tetapi kalau belum dicatatkan pada kantor pemerintah yang berwenang (baik Kantor Urusan Agama/KUA untuk yang beragama Islam ataupun Kantor Catatan Sipil/KCS untuk yang diluar Islam), maka perkawinan tersebut belum diakui sah oleh negara. Dalam berbagai kasus, sahnya suatu perkawinan secara yuridis memang harus dibuktikan melalui buku nikah yang diperoleh dari KUA dan KCS. Hal ini tentu saja menimbulkan implikasi hukum dan sosial yang beragam bagi pasangan yang berbeda agama seperti misalnya anak-anak yang lahir tidak akan dianggap sebagai keturunan yang sah dan suami-istri pun mengalami kesulitan memperoleh hak-hak keperdataan yang timbul

\footnotetext{
${ }^{11}$ Ibid, h. 99

${ }^{12}$ Ibid.
} 
dari perkawinan tersebut. Problem lain yang muncul dari sahnya sebuah perkawinan harus dicatatkan adalah bahwa pencatatan tersebut hanya berlaku bagi agama-agama yang diakui oleh negara sebagaimana yang tertuang dalam UU No 1/PNPS/1965 dimana agama-agama yang diakui di Indonesia hanya ada lima yaitu Islam, Kristen, Katholik, Hindu, Buddha dan Kong Hu Chu. Di luar itu, hak sipilnya tidak diakui negara sehingga orang yang di luar enam agama tersebut jika menikah dan ingin diakui negara, maka dia harus membohongi negara dan diri sendiri.

\section{b. Perkawinan Sirri}

Secara literal Nikah Sirri berasal dari bahasa Arab yang terdiri dari dua kosa kata yaitu "nikah"dan "sirri". Nikah yang menurut bahasa artinya mengumpulkan, saling memasukkan, dan digunakan untuk arti bersetubuh (wathi). ${ }^{13}$ Kata "nikah" sering dipergunakan untuk arti persetubuhan (coitus), juga untuk arti akad nikah. ${ }^{14}$ Sedangkan kata sirri berasal dari bahasa Arab "sirr" yang berarti rahasia. ${ }^{15}$

Kawin sirri adalah perkawinan yang dilakukan oleh sepasang kekasih tanpa ada pemberitahuan (dicatatkan) di Kantor Urusan Agama (KUA), tetapi perkawinan ini sudah memenuhi unsurunsur perkawinan dalam Islam, yang meliputi dua mempelai, dua orang saksi, wali, ijab-qabul dan juga mas kawin. Kawin sirri ini hukumnya sah menurut agama, tetapi tidak sah menurut hukum positif (hukum negara). Oleh karena itu, perkawinan sirri yang tidak dicatatkan di Kantor Urusan Agama itu tidak punya kekuatan hukum, sehingga jika suatu saat mereka berdua punya permasalahan yang berkenaan dengan rumah tangganya seperti perceraian, kekerasan dalam rumah tangga, warisan, perebutan hak asuh anak dan lainnya, pihak kantor urusan agama

${ }^{13}$ Abd.Rahman Gazaly, Fiqh Munakahat, (Jakarta: Kencana, 2006), h. 71

14 Abddullah bin Nuh dan Umar Bakri, Kamus Arab Indonesia Inggris, (Jakarta: Penerbit Mutiara, 1984), h. 132

15 Departemen Pendidikan Nasional, Kamus Besar Bahasa Indonesia, Edisi Ketiga, (Jakarta: Balai Pustaka, 2001), h 518 dan pengadilan agama tidak bisa memutuskan bahkan tidak bisa menerima pengaduan mereka berdua yang sedang punya masalah. ${ }^{16}$

Dari sudut pandang hukum yang berlaku di Indonesia, nikah sirri merupakan perkawinan yang dilakukan tidak sesuai dengan ketentuan peraturan perundang-undangan yang berlaku. Berdasarkan ketentuan Pasal 2 ayat (1) dan (2) UU No.1/1974 Jo. Pasal 4 dan Pasal 5 ayat (1) dan (2) KHI, suatu perkawinan di samping harus dilakukan secara sah menurut hukum agama, juga harus dicatat oleh pejabat yang berwenang. Dengan demikian, dalam perspektif peraturan perundang-undangan, nikah sirri adalah pernikahan illegal dan tidak sah.

\section{c. Perkawinan Sejenis}

Pasal 1 Undang-undang No. 1 Tahun 1974 Tentang Perkawinan, yang dikatakan "Perkawinan ialah ikatan lahir batin antara seorang pria dengan seorang wanita sebagai suami istri dengan tujuan membentuk keluarga (rumah tangga) yang bahagia dan kekal berdasarkan Ketuhanan Yang Maha Esa”. Berdasarkan Pasal 1 Undang-Undang Perkawinan tersebut jelas bahwa perkawinan hanya dilakukan oleh seorang pria dan seorang wanita sebagai suami istri.

Di Indonesia sendiri Pernikahan itu merupakan suatu perbuatan yang tidak hanya melibatkan dua insan manusia antara laki-laki dan perempuan saja tetapi juga melibatkan khalayak masyarakat banyak terutama kedua keluarga pasangan yang ingin menikah. Mengingat pernikahan yang sah adalah pernikahan yang berlangsung sesuai dengan agama masing-masing, sesuai Pasal 2 Ayat 1 Undang-undang Perkawinan yang mengatakan "Perkawinan adalah sah, apabila dilakukan menurut hukum masing-masing agamanya dan kepercayaannya itu", tentunya kehidupan sosial di Indonesia yang sarat akan tradisi dan adat istiadat yang hidup di tengah masyarakat juga berpengaruh di dalam suatu proses pernikahan tersebut sehingga erat kaitannya dengan keluarga

${ }^{16}$ Nasiri, Praktik Prostitusi Gigolo ala Yusuf Al-Qardawi (Tinjauan Hukum Islam), (Surabaya: Khalista,2010), h. 45-46. 
dan masyarakat banyak. Secara legal status pernikahan yang di akui di Indonesia hanyalah pernikahan yang berlangsung menurut agama masing-masing dan hukum yang berlaku di negara ini. Pernikahan hanya dapat berlangsung antara seorang laki-laki dan perempuan, bukan halnya antara laki-laki dengan laki-laki (Homo Seksual) dan begitu pula perempuan dengan perempuan (Lesbian) pernikahan seperti ini selain tidak di kenal dalam agama yang dianut oleh rakyat Indonesia juga bertentangan dengan sistem hukum itu sendiri, dalam hal ini undangundang perkawinan yang menjadi landasan bagi negara untuk mengakui dan mencatat peristiwa pernikahan tersebut.

Begitu pulanya dengan ajaran agama yang dianut oleh masing-masing warga negara Indonesia, tidak ada satu agama pun di negara ini yang melegalkan pernikahan sejenis, mengingat agama adalah sebagai tuntunan atau pedoman hidup untuk meraih kedamaian atau kesejahteraan bagi setiap pemeluknya, seperti misalnya agama Islam yang telah jelas-jelas melarang dan mengutuk pernikahan sejenis tersebut, sebagaimana firman Allah Swt:

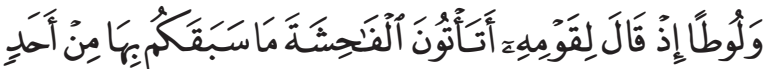

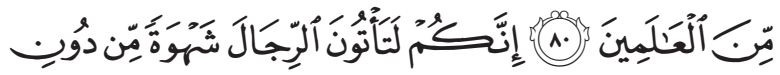

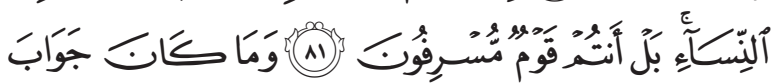

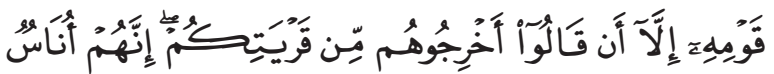

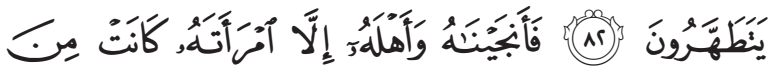

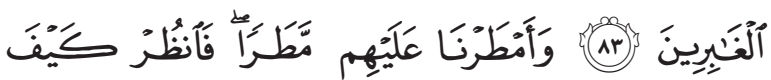

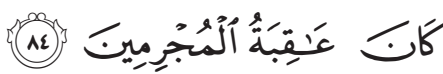

"Dan (Kami juga telah mengutus) Luth (kepada kaumnya). (Ingatlah) tatkala dia berkata kepada mereka: "Mengapa kamu mengerjakan perbuatan faahisyah (keji) itu, yang belum pernah dikerjakan oleh seorangpun (di dunia ini) sebelummu?" Sesungguhnya kamu mendatangi lelaki untuk melepaskan nafsumu (kepada mereka), bukan kepada wanita, malah kamu ini adalah kaum yang melampaui batas. Jawab kaumnya tidak lain hanya mengatakan: "Usirlah mereka (Luth dan pengikut- pengikutnya) dari kotamu ini; sesungguhnya mereka adalah orang-orang yang berpura-pura mensucikan diri. Kemudian Kami selamatkan dia dan pengikut-pengikutnya (yang beriman) kecuali istrinya (istri Nabi Luth); dia termasuk orang-orang yang tertinggal (dibinasakan). Dan Kami turunkan kepada mereka hujan (batu); maka perhatikanlah bagaimana kesudahan orang-orang yang berdosa itu." (Q.S. Al-A'raf [7]: 80-84).

Tujuan pernikahan adalah untuk memperoleh keturunan dan melestarikan kehidupan manusia. Melalui pernikahan yang sah akan muncul keturunan yang sah dan diakui di hadapan hukum. Munculnya keturunan baru manusia hanya dapat diwujudkan jika pernikahan dilakukan oleh pasangan laki-laki dan perempuan. Tanpa pernikahan maka akan sulit untuk melestarikan keturunan, kalaupun dapat menurunkan manusia baru, biasanya tidak akan baik karena berasal dari hubungan yang tidak sah dan tentu juga berpengaruh terhadap kualitas manusia itu sendiri. Jika pernikahan yang dilakukan adalah pernikahan sesama jenis, akan lebih mustahil lagi untuk memperoleh keturunan. Lambat laun manusia akan punah jika pernikahan sesama jenis ini dibenarkan. Pernikahan bukan sekedar sarana untuk melampiaskan hawa nafsu, mengelola keuangan maupun kesenangan semata, namun di dalamnya terdapat misi yang mulia yaitu menghasilkan generasi manusia yang unggul dan berkualitas. Jadi bukan hanya dari pandangan agama, gagasan pernikahan sejenis juga tidak masuk dalam logika yang benar.

\section{d. Kawin Kontrak}

Kawin kontrak yaitu perkawinan yang dilakukan oleh seorang laki-laki dan seorang perempuan yang melangsungkan pernikahan dalam jangka waktu tertentu dan dituangkan ke dalam sebuah kontrak. Kawin kontrak dalam Islam disebut dengan istilah nikah mutah. Hukumnya adalah haram dan akad nikahnya tidak sah alias batal. Hal ini sama saja dengan orang sholat tanpa berwudhu', maka sholatnya 
tidak sah alias batal. Tidak diterima oleh Allah Swt sebagai ibadah. Demikian pula orang yang melakukan kawin kontrak akad nikahnya tidak sah alias batal, dan tidak diterima Allah Swt sebagai amal ibadah, sebab nash-nash dalam Alquran maupun Hadis tentang pernikahan tidak mengkaitkan pernikahan dengan jangka waktu tertentu. Pernikahan dalam Alqurandan Hadis ditinjau dari segi waktu adalah bersifat mutlak, yaitu maksudnya untuk jangka waktu selamanya, bukan untuk jangka waktu sementara. Maka dari itu, melakukan kawin kontrak yang hanya berlangsung untuk jangka waktu tertentu hukumnya tidak sah, karena bertentangan ayat Alquran dan Hadis yang sama sekali tidak menyinggung batasan waktu. ${ }^{17}$

Kawin kontrak atau kawin mut'ah yang banyak dikenal di beberapa daerah di Indonesia adalah perkawinan di bawah tangan yang dilakukan dua calon pengantin dengan perjanjian dalam suatu waktu tertentu. Karena dilakukan di bawah tangan, maka perkawinan ini tidak didaftarkan ke instansi berwenang. Dalam hukum, kawin kontrak sebenarnya tidak diperkenankan, karena sebagaimana ketentuan Undang-Undang Nomor 1 Tahun 1974 tentang Perkawinan. Pasal 1 Undang-Undang Perkawinan menyatakan bahwa: Perkawinan ialah ikatan lahir batin antara seorang pria dengan seorang wanita sebagai suami istri dengan tujuan membentuk keluarga ( rumah tangga) yang bahagia dan kekal berdasarkan Ketuhanan Yang maha Esa. Selanjutnya Pasal 2 ayat (1) menyatakan bahwa Perkawinan adalah sah apabila dilakukan menurut hukum masing-masing agamanya dan kepercayaannya itu. Artinya, jika perkawinan dilakukan tidak berdasarkan agama dan kepercayaan dari masing-masing pihak, maka secara hukum tidak akan diakui keabsahannya. Ketentuan agama dalam hal ini tidak hanya diberi pengertian terpenuhinya syarat-syarat konkrit seperti adanya dua calon mempelai, persetujuan orang tua, maupun mahar, dan

17 M. Shiddiq Al Jawi, 11 Mei 2013, Kawin Kontrak Menurut Hukum Islam, https://hizbut-tahrir.or.id/, diakses tgl 14 November 2016. lain-lainnya, tetapi juga harus terpenuhinya tujuan dari perkawinan itu sendiri yaitu untuk membentuk sebuah keluarga yang bahagia lahir dan batin berdasarkan ketuhanan Yang Maha Esa.

Oleh karenanya, kawin kontrak bukan merupakan perkawinan yang sah karena pada dasarnya dilakukan bukan karena tujuan mulia untuk mematuhi perintah Tuhan dan untuk membentuk keluarga yang bahagia, melainkan hanya untuk memenuhi tujuan-tujuan yang didasari kepentingan ekonomi atau biologis semata. Selain itu, kawin kontrak juga melanggar ketentuan Undang-Undang Perkawinan, karena tiap perkawinan harus dicatatkan, sebagaimana bunyi pasal 2 ayat (2 ) Undang-Undang Perkawinan. Begitu juga hal yang penting diingat, bahwa kawin kontrak akan merugikan anak yang dihasilkan dari kawin tersebut, karena sang anak tidak memiliki status atau ayah yang sebenarnya.

\section{Penutup}

Bangsa Indonesia terdiri dari berbagai macam suku, golongan, ras dan agama serta kaya akan budaya. Heteroginitas masyarakat Indonesia sangat memungkinkan terjadinya perkawinan beda agama dan bentuk-bentuk perkawinan lainnya. Aturan dalam hukum perkawinan pun bersifat pluralisme, artinya bahwa aturan perkawinan yang diatur menurut hukum positif Indonesia, terdiri dari hukum agama, hukum negara, bahkan hukum perkawinan adat. Dalam penjelasan undang-undang perkawinan ditegaskan dengan perumusan Pasal 2 Ayat 1 tersebut bahwa tidak ada perkawinan di luar hukum masing-masing agamanya dan kepercayaannya itu, sesuai dengan UUD 1945.

Dewasa ini banyak terjadi berbagai problematika dalam hukum perkawinan Indonesia, meliputi perkawinan beda agama, perkawinan sesama jenis, perkawinan sirri dan perkawinan kontrak. Mengenai perkawinan beda agama sangat jelas dilarang oleh agama Islam dan umumnya juga berlaku bagi agama 
selain Islam. Perkawinan sejenis juga sangat dilarang dalam hukum agama dan hukum negara, karena pada dasarnya salah satu tujuan perkawinan adalah memperoleh keturunan dan melestarikan kehidupan manusia. Sedangkan perkawinan sirri dan perkawinan kontrak merupakan perkawinan yang dilaksanakan secara illegal karena tidak dicatatkan di Kantor Urusan Agama maupun Kantor Catatan Sipil. Indonesia memang bukan negara agama, tetapi menganut asas Ketuhanan Yang Maha Esa di mana semua warga negara Indonesia adalah orang yang beragama. Masih banyak aturan yang perlu diubah maupun ditambah di dalam Undang-Undang Perkawinan, misalnya mengenai aturan/ketentuan mengenai sanksi yang tegas bagi para pelanggar hukum perkawinan, baik itu bagi pelaku perkawinan beda agama, perkawinan sejenis, perkawinan sirri maupun perkawinan kontrak. Oleh sebab itu, perlu dilakukan revisi terhadap Undang-Undang Nomor 1 tahun 1974 tentang Perkawinan.

\section{Pustaka Acuan}

Departemen Pendidikan Nasional, Kamus Besar Bahasa Indonesia, Edisi Ketiga, Jakarta: Balai Pustaka, 2001.

Fuaddudin, Pengasuhan Anak dalam Keluarga Islam, Lembaga Kajian Agama dan Jender, Jakarta, 1999

Gazaly, Abd. Rahman, Figh Munakahat, Jakarta: Kencana, 2006.
M. Shiddiq Al Jawi, 11 Mei 2013, Kawin Kontrak Menurut Hukum Islam, https://hizbut-tahrir. or.id/,

Meliala, Djaja S., Hukum Perdata Dalam Perspektif BW, Bandung: Nuansa Aulia, 2012.

Narsikun, Poligami Ditinjau dari Segi Agama. Sosial dan Perundang-undangan, Jakarta: Bulan Bintang, 2003.

Nasiri, Praktik Prostitusi Gigolo ala Yusuf AlQardawi (Tinjauan Hukum Islam), Surabaya: Khalista, 2010.

Nuh, Abddullah bin dan Umar Bakri, Kamus Arab Indonesia Inggris, Jakarta: Penerbit Mutiara, MCMLXXIV.

Ramulyo, Idris, Hukum Perkawinan Islam; Suatu Analisis Dari UU No.1 Tahun 1974 Dan Kompilasi Hukum Islam, Jakarta: Bumi Aksara, 2004.

Rasidi, Lili, Hukum Perkawinan dan Perceraian di Malaysia dan Indonesia, Bandung: Remaja Rosdakarya, 1991.

Soekanto, Soerjono, Pengantar Penelitian Hukum, UI Press, Jakarta, 2008.

Sudarsono, Hukum Perkawinan Nasional, Jakarta: Rineka Cipta, 2005.

Syarifuddin, Amir, Hukum Perkawinan Islam di Indonesia; Antara Fiqh Munakahat dan Undang-Undang Perkawinan, Jakarta: Kencana, 2009.

Undang-Undang Nomor 1 Tahun 1974 Tentang Perkawinan. 